\title{
Effects of warming and shifts of pelagic food web structure on benthic productivity in a coastal marine system
}

\author{
A.-K. Eriksson Wiklund ${ }^{1, *}$, K. Dahlgren ${ }^{2,3}$, B. Sundelin ${ }^{1}$, A. Andersson ${ }^{2,3}$ \\ ${ }^{1}$ Department of Applied Environmental Science, ITM, Stockholm University, 10691 Stockholm, Sweden \\ ${ }^{2}$ Department of Ecology and Environmental Science, Umeå University, 90187 Umeå, Sweden \\ ${ }^{3}$ Umeå Marine Sciences Centre, 91020 Hörnefors, Sweden
}

\begin{abstract}
It has been predicted that climate change will lead to increased temperature and precipitation in northern latitudes, which in turn may lead to brownification of coastal sea areas. This will increase the importance of the heterotrophic microbial food web in areas like the northern Baltic Sea. Such a structural change in the pelagic food web would hamper benthic productivity, since microheterotrophs have lower settling rates than phytoplankton. We tested how variation in temperature and alteration of the pelagic food web structure affected the productivity of a key benthic species, the amphipod Monoporeia affinis, and the pelagic-benthic food web efficiency (FWE). Using water from the northern Baltic Sea, a mesocosm experiment was performed in which the temperature was altered by $5^{\circ} \mathrm{C}$. The structure of the pelagic food web changed from one based on algae to one based on bacteria. Amphipod productivity was 3 times higher and FWE was 25 times higher in the algae than in the bacteria-based food web, showing that an altered pelagic food web will have severe effects on benthic productivity. Temperature variation, on the other hand, did not cause any changes in either growth of $M$. affinis or FWE. Our data indicate that indirect effects of climate change, leading to structural changes in the pelagic food web, will have much more severe effects on benthic productivity than the direct effect of increased temperature.
\end{abstract}

KEY WORDS: Climate change - Altered pelagic food web structure $\cdot$ Decreased benthic productivity . Pelagic-benthic coupling $\cdot$ Monoporeia affinis

\section{INTRODUCTION}

Monoporeia affinis (Lindström, 1855) (Amphipoda: Crustacea) is a key species of oxygenated soft bottoms in the Baltic Sea (Laine et al. 1997). During the last decade, the most dramatic population decline ever observed for $M$. affinis was recorded in the Gulf of Bothnia, in the northern Baltic Sea (Aljetlawi 2003). Populations of $M$. affinis in this area normally show cyclic fluctuations lasting 6 to $7 \mathrm{yr}$, but in 1999 a dramatic decline started in coastal areas followed by declines offshore during 2002 and 2003. The reason for this population decrease has not yet been elucidated. However, Eriksson Wiklund et al. (2008) suggested that the preceding high amphipod densities, in combination with a decrease in phytoplankton primary production, led to severe food limitation. It has not been shown that food shortage alone caused the decline, but starved individuals are more susceptible to other types of stressors such as contaminants and parasitic infestation. Interestingly, a similar large-scale decline has been observed for a related amphipod species (Diporeia spp.) in the Great Lakes of North America, where populations declined by $90 \%$ from 1993 to 2002 (Nalepa et al. 2006). Several plausible hypotheses have been suggested for the drastic declines: competition, new anthropogenic substances, hypoxia, predation and food limitation (Nalepa et al. 2006, Watkins et al. 2007). Even if drastic declines of related benthic species in different habitats are not caused by the same factor, it indicates that amphipods are very sensitive to environmental change. Extinction of such important keystone species may have drastic consequences for the functioning of the aquatic ecosystem. 
Monoporeia affinis is a deposit feeder, which preferably feeds on fresh, newly settled phytoplankton (Aljetlawi et al. 2000). Between periods of phytoplankton blooms, the amphipods can survive without food, or subsist on low quality food, by using energy stored as lipids. This strategy is facilitated by low temperatures in their soft-bottom habitat (Lehtonen 1994). Their main period of growth is in the spring after the phytoplankton bloom (Cederwall 1977, Lehtonen \& Andersin 1998). The effects of seasonal sedimentation patterns on growth and population dynamics of benthic organisms demonstrate the importance of the pelagic-benthic coupling (Karlson et al. 2007).

Basal pelagic production (phytoplankton primary production + bacterial production) in the Gulf of Bothnia varies along a north-south gradient from $\sim 30$ to $65 \mathrm{~g} \mathrm{C} \mathrm{m}^{-2} \mathrm{yr}^{-1}$ (Samuelsson et al. 2006). In the Bothnian Bay (extreme north), about $50 \%$ of the basal production is contributed by bacteria and $50 \%$ by phytoplankton. In the Bothnian Sea (south), $75 \%$ of the production is contributed by phytoplankton and $25 \%$ by bacteria. The reason for relatively high bacterial production in the north is a combination of low nutrient availability and a high inflow of allochthonous organic C (Sandberg et al. 2004). This causes an uncoupling of the bacterial and phytoplankton production. Production during the spring bloom is dominated by lipid and energy-rich diatoms and dinoflagellates (Andersson et al. 1993). A difference in spring bloom production of approximately one order magnitude between the north and the south of the Gulf of Bothnia (Andersson et al. 1996) may cause the difference in abundance of amphipods in this sea area. Before the drastic decline, the abundance of Monoporeia affinis was approximately one order of magnitude higher in the Bothnian Sea than in the Bothnian Bay, whilst after the crash abundances in the 2 basins were more similar, i.e. 3 times higher in the Bothnian Sea (Monitoring data, SHARK database, SMHI, Sweden).

Temperature alterations affect both the magnitude of the spring bloom and composition of the phytoplankton community (Andersson et al. 1994, Keller et al. 1999, Müren et al. 2005, Sommer et al. 2007). Higher temperature favours nanophytoplankton over larger species such as diatoms (Hare et al. 2007). This also affects sinking ability, since smaller algae have a lower sinking rate (Smayda 1970) leading to reduced spring bloom sedimentation (Keller et al. 1999, Müren et al. 2005, Sommer et al. 2007).

It has been predicted that climate change will cause increased river inflow and hence decreased salinities in the Baltic Sea, especially in the north (Meier 2006, HELCOM 2007). Salinity may decrease by up to $50 \%$. Since river water in this area is rich in humic substances and allochthonous organic $\mathrm{C}$ and poor in $\mathrm{P}$, phytoplankton will possibly be disadvantaged in the future, whilst bacteria will be promoted or unaffected. It is likely that such changes at the base of the food web will have severe effects at higher trophic levels. We can infer from predicted indirect effects of climate change and predicted direct effects of increasing temperature that the main food source for amphipods will decrease in the future.

Decreased nutrient availability, poorer light conditions, and higher temperatures in concert may in the future cause decreased phytoplankton production or reduced spring blooms. In contrast, bacterial production may not be affected since the $\mathrm{C}$ source of the bacteria, based on phytoplankton, may be replaced by allochthonous $\mathrm{C}$ originating from the terrestrial system. We believe that in the future the basal trophic level will be based more on bacteria than on phytoplankon. We have tested how such a structural change, as well as a temperature increase, would affect the productivity of the key amphipod species, Monoporeia affinis.

Our main hypothesis was that growth of Monoporeia affinis and food web efficiency (FWE) would be significantly hampered in a bacteria-based food web compared to a phytoplankton-based one. Bacteria have a lower nutritional value and do not sediment. There are also relatively more trophic levels in bacteria-based food webs. This results in greater losses of organic C, since at each level $70 \%$ of the ingested $C$ is lost due to respiration and sloppy feeding (Straile 1997). Our second hypothesis was that temperature would affect amphipods differently depending on the food web. Higher temperatures would result in less amphipod growth in the phytoplankton-based web due to the promotion of smaller individuals less prone to sedimentation than larger cells. In a bacteria-based food web, increased temperature would promote growth of the amphipod because of the greater rate of production of larger plankton and aggregates, which may sediment to the benthos. To test these hypotheses, we performed a mesocosm experiment using water from the northern Baltic Sea. Amphipod growth and food web efficiency were analysed after 8 wk of incubation for both an algae- and a bacteria-based food web, in combination with high and low temperatures. Possible effects of climate change on the Baltic Sea ecosystem are discussed.

\section{MATERIALS AND METHODS}

Experimental setup and sampling. We subjected juvenile specimens of Monoporeia affinis to 4 different treatments, 2 temperatures and 2 pelagic food sources in a mesocosm experiment for 2 mo (Fig. 1). The food 


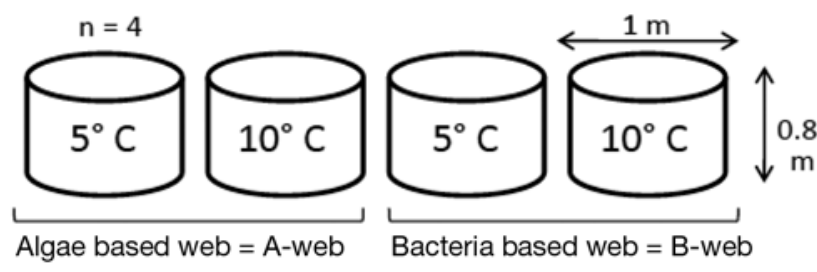

Fig. 1. Experimental setup, showing size of the mesocosms and 4 mesocosm treatments ( $\mathrm{n}=4$ in all treatments). Two temperatures were used, 5 and $10^{\circ} \mathrm{C}$, in combination with 2 food webs, one algae-based (A-web) and one bacteria-based (B-web)

sources consisted of 2 different pelagic food webs, one mainly phytoplankton-based (the A-web) and one bacteria-based (the B-web). The food webs consisted of natural bacteria, phytoplankton, protozoa and zooplankton communities (zooplankton and protozoan data will be presented elsewhere; K. Dahlgren unpubl.). The 4 treatments will henceforth be called $5^{\circ} \mathrm{C}$ A-web, $10^{\circ} \mathrm{C} \mathrm{A}$-web, $5^{\circ} \mathrm{C} \mathrm{B}$-web and $10^{\circ} \mathrm{C}$ B-web.

The experiment was performed in a flow-through mesocosm system consisting of 16 barrels. The in- and out-flow of water in the mesocosms was $2.15 \mathrm{l} \mathrm{h}^{-1}$ (water residence time $\sim 10 \mathrm{~d}$ ); both the inlet and outlet passed through a $100 \mu \mathrm{m}$ mesh net. Each barrel was aerated using a small oxygen pump. The bottom of each barrel was covered to a depth of $4 \mathrm{~cm}$ with clean natural sand which was covered with $4 \mathrm{l}$ sieved sediment, corresponding to a layer $\sim 1 \mathrm{~mm}$ thick ( $\mathrm{C}$ content $<2 \%$ ), to give the amphipods a more natural environment in which to acclimatise. Incoming water was at ambient temperature and was either slightly heated or cooled. The lower temperature was created by plastic tubes (WirsboPePEX) containing running water, at $5^{\circ} \mathrm{C}$, encircling the inside of each low temperature mesocosm. Higher temperature was achieved using immersion heaters. Temperature remained stable throughout the experiment, differing $\pm 1{ }^{\circ} \mathrm{C}$ from the target.

We used a $12 \mathrm{~h}$ day length (Philips Xenon, $150 \mathrm{~W}$ ) and the surface irradiance (photosynthetic active radiation) in the centre of the tanks was $\sim 100$ to $200 \mu \mathrm{mol}$ quanta $\mathrm{m}^{-2} \mathrm{~s}^{-1}$ in the A-web treatment and $\sim 1 \mu \mathrm{mol}$ quanta $\mathrm{m}^{-2}$ $\mathrm{s}^{-1}$ in the B-web treatment. The A-web mesocosms were placed on top of the B-web mesocosms with a $1 \mathrm{~m}$ space between them to accomplish samplings. To acclimatise the amphipods to a more intense light regime compared to their in situ habitat, we used a lower intensity during the first weeks of the experiment.

A phytoplankton-based pelagic food web was created by the addition of $\mathrm{N}$ and $\mathrm{P}$ twice a week, in the forms of ammonium $0.53 \mu \mathrm{mol} \mathrm{l}^{-1} \mathrm{~d}^{-1}$, nitrate $3.15 \mu \mathrm{mol}$ $\mathrm{l}^{-1} \mathrm{~d}^{-1}$ and phosphate $0.23 \mu \mathrm{mol} \mathrm{l}^{-1} \mathrm{~d}^{-1}$. To create a bacteria-based food web, C, P and $\mathrm{N}$ were added. C was in the form of glucose $\left(4.07 \mu \mathrm{mol} \mathrm{l}^{-1} \mathrm{~d}^{-1}\right)$, while $\mathrm{N}$ and $\mathrm{P}$ additions corresponded to those for the phytoplankton- based web. Si was not added since the coastal waters of the Bothnian Sea contain high concentrations of $\mathrm{Si}$ (Andersson et al. 1996, Monitoring data, SHARK database, SMHI, Sweden).

Due to the low amphipod abundance in the Bothnian Sea, the amphipods were collected at a reference site outside Stockholm University Marine Field station at $58^{\circ} 49^{\prime} \mathrm{N}, 17^{\circ} 38^{\prime}$ at 30 to $40 \mathrm{~m}$ depth in the Baltic proper. The amphipods were sorted into age classes and 700 juvenile amphipods were added to each mesocosm, resulting in an amphipod density of $\sim 900$ ind. $\mathrm{m}^{-2}$. Previous experiments (e.g. Berglund et al. 2007) have shown that, at the selected density, the pelagic $C$ production aimed for in this experiment would not limit amphipod growth (Kotta \& Ólafsson 2003). The amphipods were sampled on 3 occasions; 1 mo after their introduction and then twice more at $2 \mathrm{wk}$ intervals. On the first 2 sampling occasions, the amphipods were collected by an Ekman grab (sampling area $0.0196 \mathrm{~m}^{2}$ giving $\sim 10$ ind. per mesocosm), equivalent to $<1.5 \%$ of the total abundance, which we assumed to have an insignificant effect on subsequent results. The grab samplings also indicated a survival of more than $60 \%$. At the termination of the experiment, an area of $\sim 20 \%$ of each barrel was sampled, after the variables in the overlying water had been quantified. The sediments were sieved and the collected amphipods put in clean water overnight to evacuate their guts.

The amphipods were then frozen at $-80^{\circ} \mathrm{C}$, freezedried, measured and weighed ( 10 from each barrel and sampling). Sizes of the amphipods were measured using image analysis (Zion Image). Three subsamples (>0.5 mg dry wt) from each barrel and sampling occasion were analysed to assess $\mathrm{C}$ and $\mathrm{N}$ content of the amphipods. The remaining amphipods were saved for further qualitative analyses to be published elsewhere (A.-K. Eriksson Wiklund unpubl.). The amphipod stable isotopic signal was measured at the end of the experiment by a PDZ Europa ANCA-GSL elemental analyzer interfaced to a PDZ Europa 20-20 isotope ratio mass spectrometer (IRMS) (Sercon Ltd., Cheshire, UK) at the stable isotope facility at University of California, Davis, USA.

We estimated pelagic food web production, enumerated microorganisms and measured chlorophyll a from the amphipod samplings, as follows.

Analyses of ambient variables. The concentrations of $\mathrm{NH}_{4}, \mathrm{NO}_{2}, \mathrm{NO}_{3}, \mathrm{PO}_{4}$ and $\mathrm{Si}(\mathrm{OH})_{4}$ were analysed using a Bran \& Luebbe TRAACS 800 autoanalyzer and standard seawater methods according to Grasshoff et al. (1983). Total phosphorus (Tot P) and total nitrogen (Tot N) were determined after the samples had been oxidized with peroxodisulphate. Dissolved organic carbon (DOC) was determined using a Shimadzu TOC-5000 high temperature catalytic oxidation instru- 
ment with non-dispersive infra-red (NDIR) detection. Samples were acidified and sparged prior to analysis. Calculation of $\mathrm{C}$ concentrations was made using potassium hydrogen phthalate as the standard substance.

Bacterial biomass and production. Enumeration of bacteria was undertaken on samples taken from the middle of the tanks. Heterotrophic bacteria and flagellates were preserved in $0.2 \mu \mathrm{m}$ filtered glutaraldehyde ( $2 \%$ final concentration). A $2 \mathrm{ml}$ sample from each barrel was filtered onto black $0.2 \mu \mathrm{m} 25 \mathrm{~mm}$ polycarbonate filters (Poretics) and stained with acridine orange (Samuelsson et al. 2002). Cell numbers and volumes were estimated using a Zeiss Axiovert 100 epifluorescence microscope at $630 \times$ magnification, followed by image analysis according to Blackburn et al. (1998). Carbon biomass (mg C cell-1) was estimated using the following formula (Norland 1993):

$$
m_{\mathrm{b}}=0.12 \times 10^{-9} \times \mathrm{CV}^{0.7}
$$

where $m_{\mathrm{b}}=$ carbon biomass $\left(\mathrm{mg} \mathrm{C} \mathrm{cell}^{-1}\right)$ and CV $=$ cell volume $\left(\mu \mathrm{m}^{3}\right)$ was multiplied by cell abundance, $N_{\mathrm{b}}$ (cells $\left.{ }^{-1}\right)$, to estimate bacterial biomass, $B_{\mathrm{b}}\left(\mathrm{mg} \mathrm{C} \mathrm{l}^{-1}\right)$

$$
B_{\mathrm{b}}=N_{\mathrm{b}} \times m_{\mathrm{b}}
$$

We used the $\left[{ }^{3} \mathrm{H}\right.$-methyl]-thymidine incorporation method (Fuhrman \& Azam 1982) to measure bacterial production. Three $1.5 \mathrm{ml}$ samples and 3 controls were incubated with $0.074 \times 10^{6} \mathrm{~Bq}\left(2.81 \times 10^{12} \mathrm{~Bq} \mathrm{mmol}^{-1}\right)$ of $\left[{ }^{3} \mathrm{H}\right.$-methyl]-thymidine in situ for $1 \mathrm{~h}$. Incubation was stopped by adding $100 \mu \mathrm{ll} 50 \%$ trichloroacetic acid (TCA) followed by centrifugation and cleaning of the pellet using $5 \%$ TCA. The samples were analysed in a scintillation counter (Beckman Coulter L S 6500) after adding $1 \mathrm{ml}$ scintillation fluid (OptiPhase 3, Perkin Elmer) and were then analysed as described in Berglund et al. (2007).

Phytoplankton biomass, primary production. To analyse phytoplankton, a sample $(100 \mathrm{ml})$ was taken from the middle of each mesocosm tank and preserved in $2 \%$ acid Lugol's solution. After sedimentation in sedimentation chambers $(10,25$ or $50 \mathrm{ml})$, the phytoplankton were counted using an inverted microscope (Nikon TE 2000). Half of each chamber was scanned for microplankton at $100 \times$ magnification and 1 or 2 diagonals using $400 \times$ magnification were scanned for nanoplankton (Berglund et al. 2007). We calculated biovolume in accordance with Olenina et al. (2006) andC content in accordance with Menden-Deuer \& Lessard (2000). The general formula for phytoplankton taxa was

$$
m_{\mathrm{p}}=0.216 \times 10^{-9} \times \mathrm{CV}^{0.939}
$$

where $m_{\mathrm{p}}$ is carbon biomass ( $\mathrm{mg} \mathrm{C}$ cell $^{-1}$ ) and CV is cell volume $\left(\mu \mathrm{m}^{3}\right)$.
Compared to other phytoplankton taxa, diatoms have lower specific $\mathrm{C}$ content and this was calculated using the formula

$$
m_{\mathrm{d}}=0.288 \times 10^{-9} \times \mathrm{CV}^{0.811}
$$

where $m_{\mathrm{d}}$ is carbon biomass (mg C cell-1) and CV is cell volume $\left(\mu^{3}\right)^{3}$. Picocyanobacteria were analysed in the flagellate samples on the basis of their autofluorescence. For each sample $>200$ cells were counted. C biomass was calculated according to Eq. (1). Since the size of the plankton governs their sedimentation rate, the phytoplankton cells/colonies/filaments were grouped into the size classes $>20 \mu \mathrm{m}, 5-20 \mu \mathrm{m}$ and $<5 \mu \mathrm{m}$. We measured primary production according to the ${ }^{14} \mathrm{C}$-method (Gargas 1975). Three $10 \mathrm{ml}$ light bottles and one dark bottle were incubated with $0.12 \times 10^{6}$ $\mathrm{Bq}\left(3.7 \times 10^{6} \mathrm{~Bq} \mathrm{mmol}{ }^{-1}\right)$ in the middle of each barrel for $3 \mathrm{~h}$.

After incubation, $300 \mu \mathrm{l} 5 \mathrm{M}$ hydrochloric acid was added to the samples and air was bubbled through them for $30 \mathrm{~min}$, to remove excess ${ }^{14} \mathrm{C}$. A volume of $15 \mathrm{ml}$ of scintillation fluid was added to each sample and the samples were analysed in a scintillation counter (Beckman Coulter LS 6500). Daily production values were calculated by multiplying the production with the ratio of total daily photosynthetically active radiation (PAR) and the PAR during the incubation period (Andersson et al. 1996). In the few replicates where primary production was negative, the value was set to zero. For analysis of chlorophyll a (chl a) 50 to $100 \mathrm{ml}$ water was filtered through GF/F filters and extracted in $95 \%$ ethanol overnight in the dark. We analysed the samples in a Perkin Elmer LS30 fluorometer (433 nm excitation wavelength and $674 \mathrm{~nm}$ emission wavelength). Analysis of particulate $\mathrm{C}$ on the GF/F filters was performed on a high temperature combustion elemental analyzer (Carlo Erba model 1108), using standard procedures and a combustion temperature of $1030^{\circ} \mathrm{C}$. Acetanilide was used as the standard and results were corrected for blank filter $\mathrm{C}$ content.

Food web efficiency. The food web efficiency (FWE) was calculated as:

$$
\mathrm{FWE}=\frac{\mathrm{AP}}{\mathrm{PP}+\mathrm{BP}}
$$

where AP is the amphipod biomass increment in mg $\mathrm{C}$ $\mathrm{dm}^{-2} \mathrm{~d}^{-1}$ at the nominal amphipod abundance used in this experiment, and net primary production (PP) and net bacterial production (BP) is given in $\mathrm{mg} \mathrm{C} \mathrm{dm}^{-2} \mathrm{~d}^{-1}$.

Statistical analyses. Differences in stable isotope signals for the amphipods were tested by 2-way ANOVA, with temperature and food-web type as fixed factors. For the variables measured at 3 sampling occasions, differences between treatments were calculated by a mixed repeated measurements model; measures repeated over time were used, with food-web type, time 
and temperature as fixed factors. Differences between slopes, comparing biomass increase were evaluated by analysis of covariance (all the above analyses were conducted using SPSS software). Data were log-transformed if required to meet the assumptions of ANOVA. The data were further explored by Partial Least Square analysis (PLS) (SIMCA 10 software).

\section{RESULTS}

Total basal pelagic production (sum of primary production and bacterial production) was generally higher in the B-web than in the A-web, on average by 70 to $130 \%$. While the data showed no significant overall differences in relation to time or temperature (Table 1,

Table 1. ANOVA in the 4 treatments: estimation of fixed and interaction effects from repeated measures analyses. FW $=$ Food web structure, Basal prod = Basal production, Bact prod = Bacterial production, Prim prod = Primary production, Chl $a=$ Chlorophyll $a$, Bact biom = Bacterial biomass, $\mathrm{DOC}=$ Dissolved organic carbon, Tot $\mathrm{P}=$ Total phosphorus, Tot $\mathrm{N}=$ Total nitrogen, $\mathrm{Chrysoph}=$ Chrysophyceae, Bacillario $=$ Bacillariophyceae, $\mathrm{FWE}=$ Food web efficiency, $\mathrm{C}$ weight $=$ Amphipod carbon weight Area $=$ Amphipod area

\begin{tabular}{|c|c|c|c|c|c|c|c|}
\hline Variable & Parameter & $F$ & $\mathrm{p}$ & Variable & Parameter & $F$ & $\mathrm{p}$ \\
\hline \multirow[t]{7}{*}{ Basal prod } & Intercept & 143 & $<0.001$ & \multicolumn{4}{|c|}{ Tot $\mathrm{P}$ (continued) } \\
\hline & FW & 16.1 & 0.001 & & Temp $\times$ Time & 0.16 & 0.850 \\
\hline & Temp & 1.36 & 0.258 & & Temp $\times$ FW & 0.11 & 0.741 \\
\hline & Time & 0.90 & 0.418 & & Time $\times$ FW & 40.2 & $<0.001$ \\
\hline & Temp $\times$ Time & 0.32 & 0.732 & Tot $\mathrm{N}$ & Intercept & 4947 & $<0.001$ \\
\hline & Temp $\times$ FW & 4.21 & 0.054 & & FW & 9.23 & 0.046 \\
\hline & Time $\times$ FW & 14.3 & $<0.001$ & & Temp & 17.4 & $<0.001$ \\
\hline \multirow[t]{7}{*}{ Bact prod } & Intercept & 77.7 & $<0.001$ & & Time & 0.83 & 0.448 \\
\hline & FW & 40.5 & $<0.001$ & & Temp $\times$ Time & 0.13 & 0.878 \\
\hline & Temp & 1.16 & 0.300 & & Temp $\times$ FW & 6.66 & 0.014 \\
\hline & Time & 2.23 & 0.147 & & Time $\times$ FW & 93.9 & $<0.001$ \\
\hline & Temp $\times$ Time & 0.87 & 0.443 & Chrysoph & Intercept & 3531 & $<0.001$ \\
\hline & Temp $\times$ FW & 11.8 & 0.005 & & FW & 3.10 & 0.10 \\
\hline & Time $\times$ FW & 8.44 & 0.004 & & Temp & 0.48 & 0.50 \\
\hline \multirow[t]{7}{*}{ Prim prod } & Intercept & 45.6 & $<0.001$ & & Time & 21.3 & $<0.001$ \\
\hline & FW & 45.4 & $<0.001$ & & Temp $\times$ Time & 0.36 & 0.70 \\
\hline & Temp & 0.005 & 0.944 & & Temp × FW & 7.82 & 0.006 \\
\hline & Time & 16.8 & $<0.001$ & & Time $\times$ FW & 0.95 & 0.35 \\
\hline & Temp $\times$ Time & 0.60 & 0.562 & Bacillario & Intercept & 2756 & $<0.001$ \\
\hline & Temp $\times$ FW & 0.32 & 0.583 & & FW & 68.5 & $<0.001$ \\
\hline & Time $\times$ FW & 15.5 & $<0.001$ & & Temp & 0.73 & 0.42 \\
\hline \multirow[t]{7}{*}{ Chl a } & Intercept & 43.1 & $<0.001$ & & Time & 10.3 & 0.002 \\
\hline & FW & 30.2 & $<0.001$ & & Temp $\times$ Time & 2.55 & 0.12 \\
\hline & Temp & 1.43 & 0.254 & & Temp $\times$ FW & 0.69 & 0.42 \\
\hline & Time & 4.05 & 0.043 & & Time $\times$ FW & 18.4 & $<0.001$ \\
\hline & Temp $\times$ Time & 0.91 & 0.427 & FWE & Intercept & 16.8 & $<0.001$ \\
\hline & Temp $\times$ FW & 5.64 & 0.035 & & FW & 14.9 & $<0.001$ \\
\hline & Time $\times$ FW & 4.62 & 0.030 & & Temp & 0.23 & 0.634 \\
\hline \multirow[t]{7}{*}{ Bact biom } & Intercept & 302 & $<0.001$ & & Time & 0.43 & 0.654 \\
\hline & FW & 1.10 & 0.316 & & Temp $\times$ Time & 0.94 & 0.404 \\
\hline & Temp & 0.02 & 0.874 & & Temp $\times$ FW & 0.03 & 0.871 \\
\hline & Time & 37.9 & $<0.001$ & & Time $\times$ FW & 1.45 & 0.251 \\
\hline & Temp $\times$ Time & 1.06 & 0.375 & C weight & Intercept & 2923 & $<0.001$ \\
\hline & Temp $\times$ FW & 0.02 & 0.887 & & FW & 55.2 & $<0.001$ \\
\hline & Time $\times$ FW & 2.92 & 0.090 & & Temp & 2.98 & 0.093 \\
\hline \multirow[t]{7}{*}{ DOC } & Intercept & 10401 & $<0.001$ & & Time & 18.4 & $<0.001$ \\
\hline & FW & 2.65 & 0.13 & & Temp $\times$ Time & 1.22 & 0.314 \\
\hline & Temp & 2.65 & 0.13 & & Temp $\times$ FW & 0.20 & 0.660 \\
\hline & Time & 71.57 & $<0.001$ & & Time $\times$ FW & 9.10 & 0.001 \\
\hline & Temp $\times$ Time & 0.004 & 0.95 & Area & Intercept & 2043 & $<0.001$ \\
\hline & Temp $\times$ FW & 16.86 & 0.001 & & FW & 17.5 & 0.001 \\
\hline & Time $\times$ FW & 0.51 & 0.49 & & Temp & 2.01 & 0.182 \\
\hline \multirow[t]{4}{*}{ Tot $\mathrm{P}$} & Intercept & 2016 & $<0.001$ & & Time & 13.1 & 0.001 \\
\hline & FW & 0.43 & 0.515 & & Temp $\times$ Time & 1.12 & 0.355 \\
\hline & Temp & 6.53 & 0.015 & & Temp $\times$ FW & 1.66 & 0.222 \\
\hline & Time & 3.19 & 0.057 & & Time $\times$ FW & 2.19 & 0.151 \\
\hline
\end{tabular}




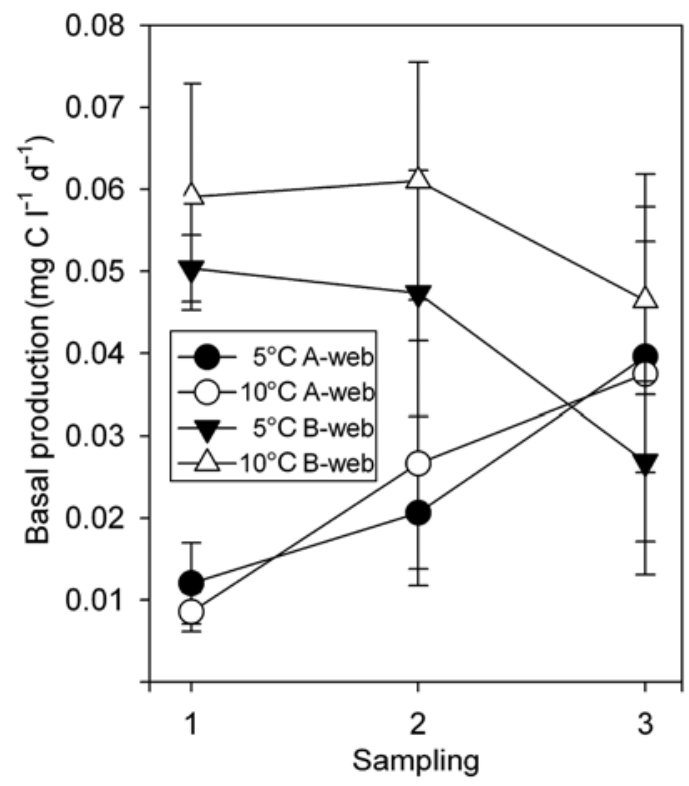

Fig. 2. Basal pelagic production (bacterial and primary production). Values are mean $\pm \mathrm{SD}$ of 4 replicates measured on 3 sampling occasions

Fig. 2), a significant interaction was observed between food web and time. This interaction is explained by the increased basal production over time in the phytoplankton-based food webs (A-webs) but its decrease in the bacteria-based food webs (B-webs). The 2 components of the basal production were also analysed separately. Bacterial production dominated the B-webs and constituted $>95 \%$ of the basal production (see Tables 1 \& 2). Primary production was, therefore, of minor importance in this food web. Bacterial production was between 3 and 10 times higher in the B-webs compared to the A-webs. In the A-webs, bacterial production was as important as primary production on the first sampling occasion, but its relative importance was reduced to $\sim 30 \%$ of the basal production as the primary production rose following the increase in light intensity. In the $\mathrm{A}$-webs, the primary production increased steadily over time in the $5^{\circ} \mathrm{C}$ treatment but peaked at the time of the second sample collection in the $10^{\circ} \mathrm{C}$ treatment (Table 2). The primary production was between 5 and 25 times higher in the A-web treatments compared to the B-webs. Bacterial biomass was generally lowest on the second sampling occasion; however no significant effects of food web or treatment were found (see Fig. 3, Table 1).

The differences in primary production between treatments were reflected in the concentration of chl a (Fig. 3) with one exception; the concentration of chl $a$ in the A-web treat- ment was higher in the lower temperature treatment (Table 1, Fig. 3). The concentration of Tot $\mathrm{N}$ was stable over time and there were slight differences between food webs (Tables $1 \& 3$ ). At each particular sampling, the concentrations of Tot $\mathrm{P}$ were higher in the low temperature treatments of each food web compared to the corresponding high temperature treatments (Tables 1 \& 3). The comcentrations of DOC were higher at the last sampling compared to the first (Tables 1 \& 3). Analysis of the $\mathrm{C}$ and $\mathrm{N}$ contents of the GF/F filters from each treatment indicated no overall effects of either temperature or food web. However, significant interaction terms were found between temperature and food web ( $\mathrm{p}<0.05,2$-way ANOVA), with the $\mathrm{C}$ and $\mathrm{N}$ content of the filters highest in the low temperature A-web (0.82 and $0.12 \mathrm{mg} \mathrm{l}^{-1}$ respectively) and in the high temperature B-web (0.77 and $0.13 \mathrm{mg} \mathrm{l}^{-1}$ respectively).

Analysis of the algal communities provides a more qualitative way of describing the food webs, which differed considerably over time (Fig. 4). On the first sampling occasion Cyanophyceae and Chrysophyceae dominated the algal community in both food webs, irrespective of temperature. This pattern continued over the second sampling, although Bacillariophyceae had begun to increase in the A-webs. The most pronounced overall result regarding the algal community was that the concentration of phytoplankton was highest in all treatments at the time of the third sampling. At this time, Chrysophyceae dominated the B-webs but concentrations were 4 times higher in the $10^{\circ} \mathrm{C} \mathrm{B}$ web compared to the $5^{\circ} \mathrm{C} \mathrm{B}$-web. There was a significant difference over time and there was a significant temperature and time interaction (see Table 1). At the last sampling in the A-webs, the algal biomass was approximately 2 times higher in the low compared to the high temperature treatment. Bacillariophyceae dominated the $5^{\circ} \mathrm{C}$ A-web treatment, while Bacillariophyceae and Chrysophyceae were of equal importance in the $10^{\circ} \mathrm{C} \mathrm{A}$-web, resulting in significant differences between food webs and over time.
Table 2. Pelagic production $\left(\times 10^{-3} \mathrm{mg} \mathrm{C}^{-1} \mathrm{~d}^{-1}\right)$ data from 3 sampling occasions: values are mean $\pm \mathrm{SD}$ of 4 replicates. $\mathrm{PP}=$ primary production, $\mathrm{BP}=$ bacteria production

\begin{tabular}{|lccccc|}
\hline \multicolumn{2}{l}{$\begin{array}{l}\text { Matrix and } \\
\text { sampling }\end{array}$} & $5{ }^{\circ} \mathrm{C}$ A-web & $10^{\circ} \mathrm{C}$ A-web & $5{ }^{\circ} \mathrm{C}$ B-web & $10^{\circ} \mathrm{C}$ B-web \\
\hline PP & 1 & $5.1 \pm 4.1$ & $3.0 \pm 2.0$ & 0 & $0.03 \pm 0.5$ \\
& 2 & $14.5 \pm 4.1$ & $22.9 \pm 12.9$ & $1.1 \pm 0.9$ & 0 \\
BP & 3 & $28.4 \pm 16.6$ & $24.1 \pm 22.8$ & 0 & $0.06 \pm 0.4$ \\
& 1 & $6.9 \pm 2.2$ & $5.5 \pm 2.7$ & $50.8 \pm 3.7$ & $\mathbf{5 9 . 1} \pm 13.9$ \\
& 2 & $6.14 \pm 2.7$ & $3.7 \pm 2.0$ & $46.3 \pm 14.8$ & $61.6 \pm 62.4$ \\
& 3 & $11.2 \pm 3.1$ & $13.4 \pm 7.4$ & $26.9 \pm 9.6$ & $46.4 \pm 11.4$ \\
\end{tabular}




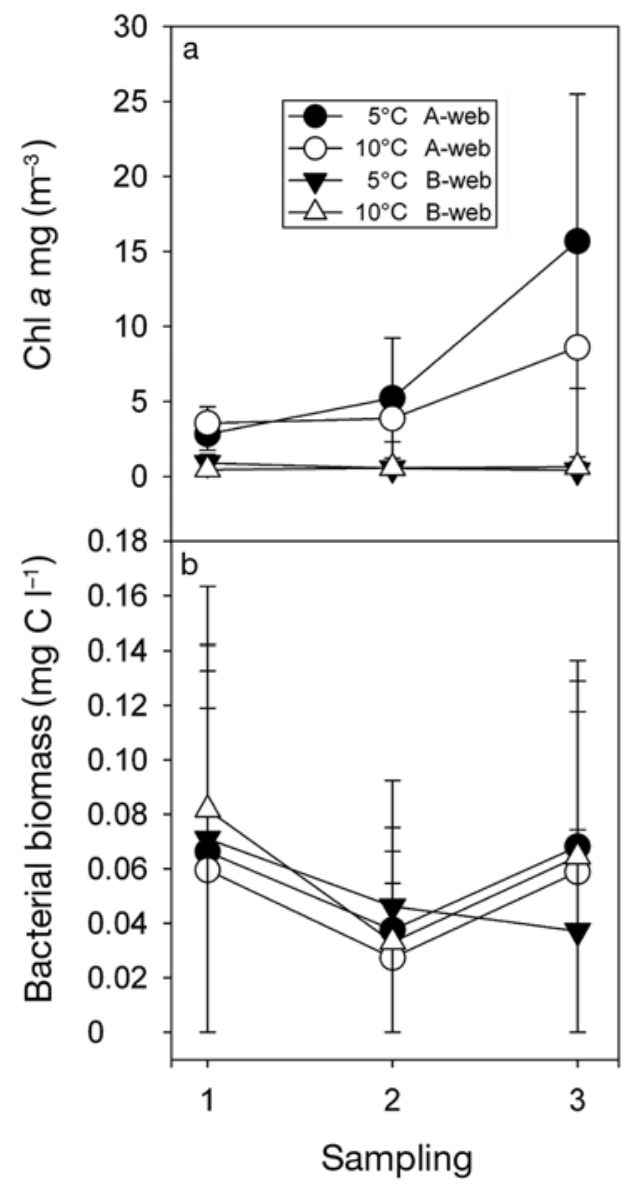

Fig. 3. Concentration of (a) chlorophyll $a$ and (b) bacterial biomass. Values are mean \pm SD of 4 replicates measured on 3 sampling occasions

Considering the phytoplankton community in relation to size distribution, it was found that the biomass of small cells, $<5 \mu \mathrm{m}$ in diameter was approximately twice as high in the A-webs compared to the B-webs, except on the last sampling occasion (Table 4). At that time, the biomass of algae $<5 \mu \mathrm{m}$ remained low in the $5^{\circ} \mathrm{C} \mathrm{B}$-web, but in the $10^{\circ} \mathrm{C} \mathrm{B}$-web they had increased to the level observed in the A-web. The concentration of the 5 to $20 \mu \mathrm{m}$ fraction was low in all treatments at the first and second samplings, but increased at least 14 -fold in all treatments at the last sampling, with the highest concentrations in the $10^{\circ} \mathrm{C}$ treatments. The biomass of algae $>20 \mu \mathrm{m}$ was low throughout the experiment in the B-webs, but in the A-webs these algae were common or dominant, especially at the end of the experiment in the $5^{\circ} \mathrm{C}$ treatment, where their biomass increased by almost 2 orders of magnitude.

Data describing amphipod growth, i.e. individual area and $\mathrm{C}$ weight of the organisms, showed differences between the food webs (Fig. 5, see Table 1). The A-webs promoted growth while the B-webs were less

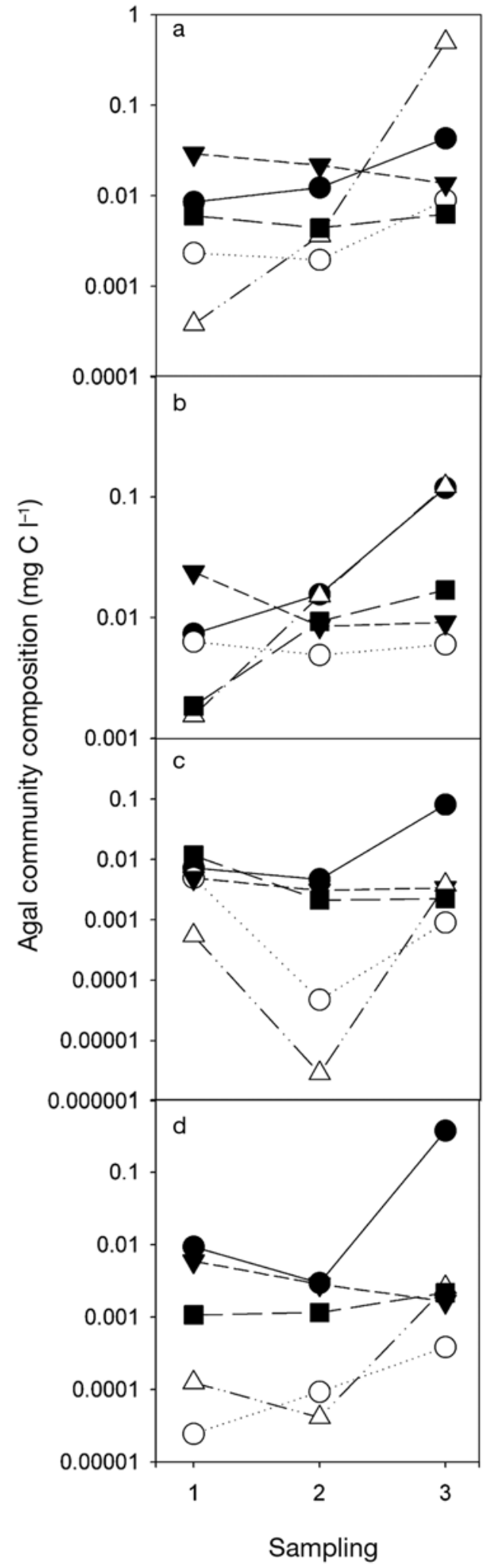

Fig. 4. Algal community composition $\left(\mathrm{mg} \mathrm{C}^{-1}\right.$ ) in (a) $5^{\circ} \mathrm{C}$ A-web, (b) $10^{\circ} \mathrm{C} \mathrm{A}$-web, (c) $5^{\circ} \mathrm{C}$ B-web and (d) $10^{\circ} \mathrm{C}$ B-web. Values are mean \pm SD of 4 replicates measured on 3 sampling occasions. (๑) Chrysophyceae, (O) Cryptophyceae, (v) Cyanophyceae, $(\Delta)$ Bacillariophyceae, ( $\mathbf{\square})$ Others 
Table 3. Nutrient concentrations $\left(\times 10^{-3} \mathrm{mmol} \mathrm{l}^{-1}\right)$ from 2 or 3 sampling occasions. Values are mean $\pm \mathrm{SE}$

\begin{tabular}{|c|c|c|c|c|c|c|c|c|c|}
\hline Sampling & Treatment & Tot $N$ & $\mathrm{NH}_{4}-\mathrm{N}$ & $\mathrm{NO}_{2}-\mathrm{N}$ & $\mathrm{NO}_{3}-\mathrm{N}$ & Tot P & $\mathrm{PO}_{4}-\mathrm{P}$ & $\mathrm{Si}$ & DOC \\
\hline \multirow[t]{4}{*}{1} & $5^{\circ} \mathrm{C} \mathrm{A}$-web & $40.8 \pm 2.8$ & $2.0 \pm 0.4$ & $0.2 \pm 0.0$ & $20.9 \pm 2.1$ & $1.5 \pm 0.2$ & $1.2 \pm 0.1$ & $49.8 \pm 2.3$ & $337.5 \pm 8.7$ \\
\hline & $10^{\circ} \mathrm{C} \mathrm{A}$-web & $38.3 \pm 1.2$ & $1.5 \pm 0.3$ & $0.2 \pm 0.1$ & $20.0 \pm 0.7$ & $1.4 \pm 0.1$ & $1.0 \pm 0.1$ & $54.8 \pm 4.2$ & $327.1 \pm 4.0$ \\
\hline & $5^{\circ} \mathrm{C}$ B-web & $34.2 \pm 1.0$ & $0.2 \pm 0.0$ & $0.2 \pm 0.0$ & $15.3 \pm 0.7$ & $1.0 \pm 0.0$ & $0.5 \pm 0.0$ & $55.2 \pm 3.5$ & $333.3 \pm 5.9$ \\
\hline & $10^{\circ} \mathrm{C} \mathrm{B}$-web & $28.3 \pm 0.8$ & $0.1 \pm 0.0$ & $0.2 \pm 0.0$ & $11.0 \pm 0.5$ & $0.9 \pm 0.1$ & $0.4 \pm 0.0$ & $51.3 \pm 1.7$ & $366.7 \pm 4.8$ \\
\hline \multirow[t]{4}{*}{2} & $5^{\circ} \mathrm{C} \mathrm{A}$-web & $40.7 \pm 2.4$ & - & - & - & $1.2 \pm 0.1$ & - & - & - \\
\hline & $10^{\circ} \mathrm{C} \mathrm{A}$-web & $38.9 \pm 1.5$ & - & - & - & $1.1 \pm 0.1$ & - & - & - \\
\hline & $5^{\circ} \mathrm{C}$ B-web & $36.8 \pm 2.0$ & - & - & - & $1.0 \pm 0.1$ & - & - & - \\
\hline & $10^{\circ} \mathrm{C} \mathrm{B}$-web & $31.4 \pm 1.2$ & - & - & - & $0.9 \pm 0.1$ & - & - & - \\
\hline \multirow[t]{4}{*}{3} & $5^{\circ} \mathrm{C} \mathrm{A}$-web & $24.3 \pm 1.2$ & $0.4 \pm 0.2$ & $0.1 \pm 0.0$ & $1.7 \pm 0.6$ & $0.9 \pm 0.1$ & $0.1 \pm 0.0$ & $1.4 \pm 0.0$ & $410 \pm 19.1$ \\
\hline & $10^{\circ} \mathrm{C} \mathrm{A}$-web & $24.1 \pm 1.0$ & $0.7 \pm 0.2$ & $0.1 \pm 0.0$ & $1.7 \pm 0.5$ & $0.8 \pm 0.0$ & $0.1 \pm 0.1$ & $0.8 \pm 0.3$ & $402.1 \pm 7.1$ \\
\hline & $5^{\circ} \mathrm{C} \mathrm{B}-w e b$ & $52.5 \pm 2.5$ & $0.3 \pm 0.0$ & $0.1 \pm 0.0$ & $32.3 \pm 2.6$ & $1.5 \pm 0.1$ & $0.9 \pm 0.1$ & $44.9 \pm 7.6$ & $396 \pm 11.0$ \\
\hline & $10^{\circ} \mathrm{C} \mathrm{B}$-web & $42.7 \pm 2.2$ & $0.3 \pm 0.2$ & $0.1 \pm 0.0$ & $28.5 \pm 4.4$ & $1.4 \pm 0.1$ & $0.9 \pm 0.1$ & $39.9 \pm 3.1$ & $429 \pm 18.2$ \\
\hline
\end{tabular}

Table 4. Phytoplankton carbon biomass $\left(\times 10^{-3} \mathrm{C}^{-1} \mathrm{~d}^{-1}\right)$ in 3 size fractions from 3 sampling occasions. Values are mean \pm SD of 4 replicates

\begin{tabular}{|lccccc|}
\hline \multirow{2}{*}{ Size fraction } & Sampling & \multicolumn{2}{c|}{$5^{\circ} \mathrm{C}$ A-web } & $10^{\circ} \mathrm{C}$ A-web & \multicolumn{2}{c|}{$5^{\circ} \mathrm{C}$ B-web } & $10^{\circ} \mathrm{C}$ B-web \\
\hline \multirow{2}{*}{$5 \mu \mathrm{m}$} & 1 & $35 \pm 10$ & $28 \pm 9$ & $9 \pm 6$ & $13 \pm 10$ \\
& 2 & $29 \pm 9$ & $17 \pm 5$ & $5 \pm 2$ & $4 \pm 1$ \\
\multirow{3}{*}{$5-20 \mu \mathrm{m}$} & 3 & $23 \pm 12$ & $35 \pm 16$ & $7 \pm 7$ & $23 \pm 25$ \\
& 1 & $14 \pm 19$ & $11 \pm 8$ & $19 \pm 28$ & $3 \pm 4$ \\
& 2 & $11 \pm 7$ & $16 \pm 7$ & $5 \pm 4$ & $2 \pm 1$ \\
$>20 \mu \mathrm{m}$ & 3 & $173 \pm 285$ & $223 \pm 393$ & $80 \pm 72$ & $357 \pm 642$ \\
& 1 & $6 \pm 8$ & $2 \pm 1$ & $0.5 \pm 0.7$ & $0.2 \pm 0.2$ \\
& 2 & $4 \pm 2$ & $20 \pm 17$ & $0.04 \pm 0.03$ & $0.1 \pm 0.1$ \\
& 3 & $371 \pm 665$ & $13 \pm 10$ & $3 \pm 3$ & $1 \pm 2$ \\
\hline
\end{tabular}

beneficial for amphipod development. We found no effect of temperature and no interaction effects. This was also shown in the principal component analysis (Fig. 6); the data points from the 2 food webs are distinctly separated, but there is no separation between barrels depending on temperature treatment. On the first sampling occasion there were only slight differences between food webs, due to low primary production as a result of the low initial light intensity. On the 2 following sampling occasions the amphipods in the A-webs increased in $\mathrm{C}$ weight throughout the experiment, while amphipods in the B-web remained at approximately the same $\mathrm{C}$ weight. By the end of the experiment, the amphipods in the A-web had gained almost twice the weight compared to the amphipods in the B-web.

Differences in individual area of the amphipods between food webs were smaller, but still significant, as the amphipods in the B-web also continued to grow in size but at a slower rate than in the A-web treatment (Fig. 5). Visual differences in growth condition were observed: the bowels of the amphipods in the A-web treatment were flanked by a yellow layer of storage lipids, while the amphipods in the B-web treatment had filled bowels but no visible lipid droplets. Comparison of growth differences, by calculation of the $\mathrm{C}$ weight growth rate, shows almost identical results for amphipods in both the $5^{\circ} \mathrm{C}$ and $10^{\circ} \mathrm{C}$ A-webs, with increases in $\mathrm{C}$ weight of $3 \times 10^{-3} \mathrm{mg} \mathrm{d}^{-1}$. The amphipods in the $2 \mathrm{~B}$-webs increased by less than $6 \times 10^{-4} \mathrm{mg} \mathrm{d}^{-1}$, and the growth in the 2 regimes was significantly different $\left(5^{\circ} \mathrm{C} \mathrm{B}\right.$-web $\mathrm{p}=0.003$, $10^{\circ} \mathrm{C}$ B-web $\mathrm{p}=0.01$ ). The stable $\mathrm{C}$ isotope signal in the amphipods differed between the A-web and the Bweb treatments (Fig. 7) $(p=0.001$, 2-way ANOVA), but there were no temperature or interaction effects. The $\mathrm{N}$ signal showed no differences between treatments. Neither time nor temperature had any effect on FWE, but the FWE was 25 times higher in the A-webs than in the B-webs (Fig. 8, see Table 1).

\section{DISCUSSION}

Amphipod growth, in terms of C-weight increase, was 3 times higher in the algal webs compared to the bacterial webs, thus supporting one of the main hypotheses of this study. This indicates that pelagic food web alterations, e.g. due to environmental change, may have drastic effects on the benthic community. The differences in amphipod response between treatments were greater in terms of weight than in terms of area and demonstrate the ability of amphipods to respond to differences in food source in terms of weight and lipid gain, as reported by Hill et al. (1992). The amphipods had the ability to respond to the higher primary production in the A-webs after the light acclimatisation period. This shows that the atypical light conditions in the A-webs were not a factor that 


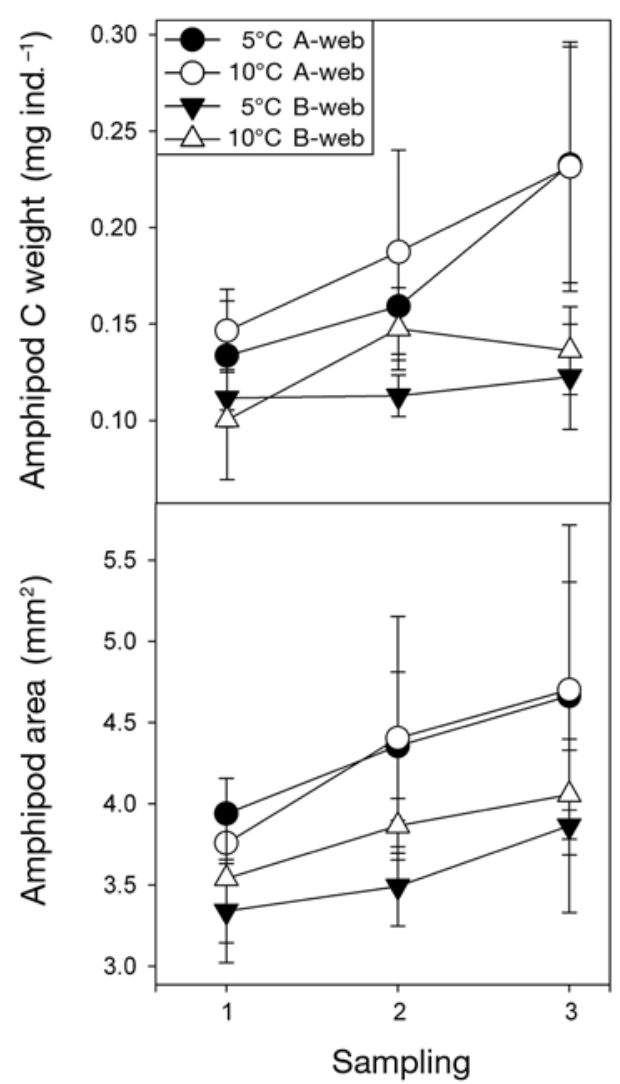

Fig. 5. (a) Amphipod carbon weight $\left(\mathrm{mg} \mathrm{C}\right.$ ind. ${ }^{-1}$ ) and (b) average size (area) of 1 individual $\left(\mathrm{mm}^{2}\right)$. Area measurements represent 4 to 6 individuals per sampling in 4 replicates. Carbon weight values are mean \pm SD of 4 replicate barrels; from each barrel 3 subsamples $>0.5 \mathrm{mg}$ dry wt were taken

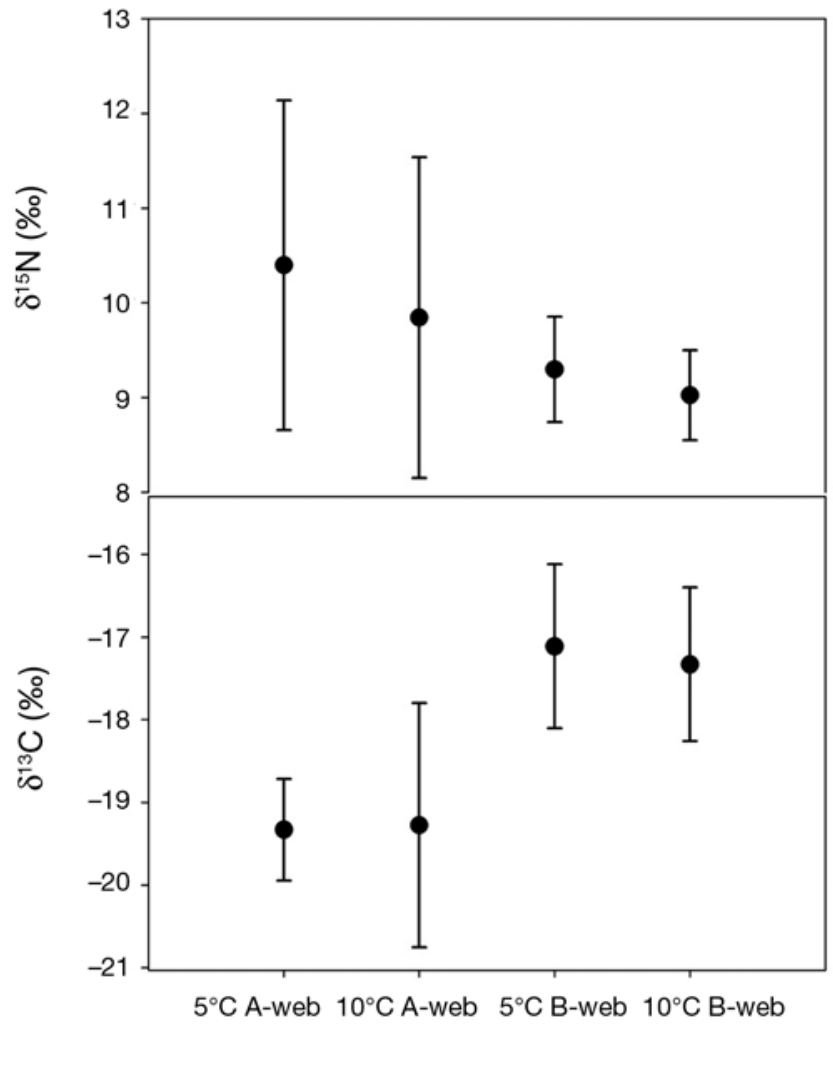

Fig. 7. Stable $\mathrm{C}$ and $\mathrm{N}$ signal in amphipods at the end of the mesocosm experiment. Values are mean $\pm \mathrm{SD}$

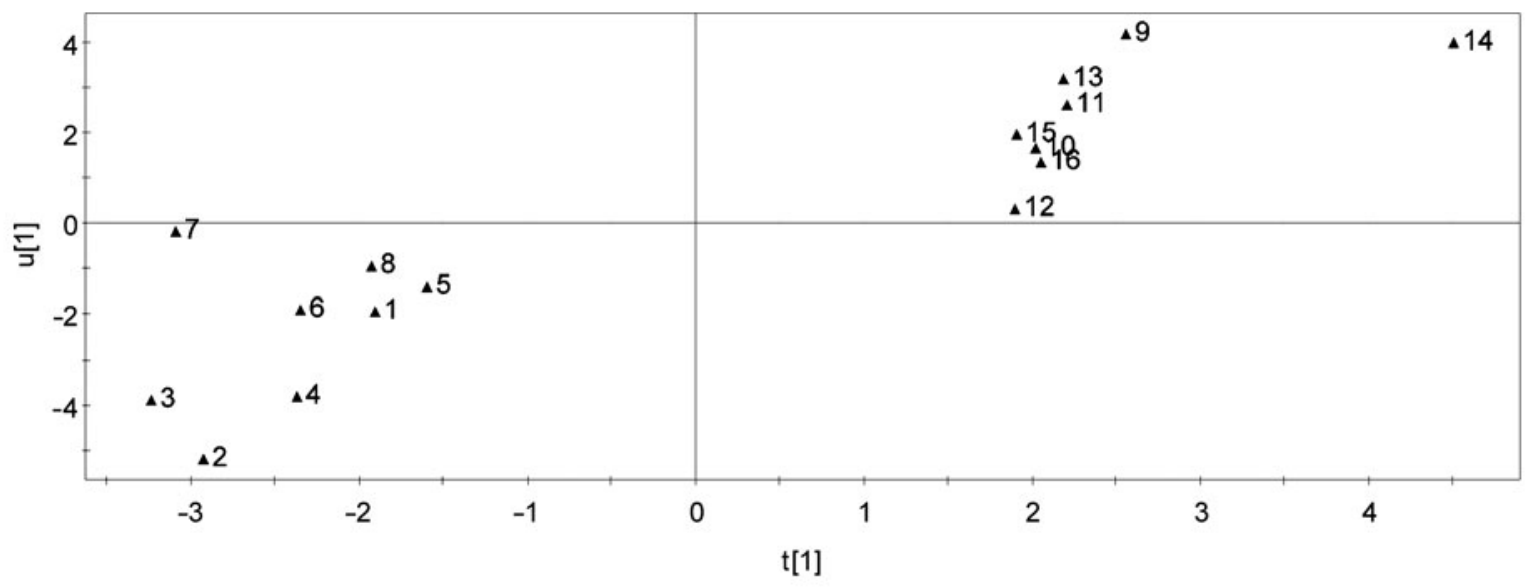

Fig. 6. Partial Least Square analysis (PLS) model of the experiment. Factors related to amphipod response $=y$-variables; factors related to the food web production $=x$-variables. Barrels 1 to 8 contained phytoplankton-based food web (A-web); barrels 9 to 16 contained bacteria-based food web (B-web). Odd numbers $=$ target temperature of $5^{\circ} \mathrm{C}$; even numbers $=10^{\circ} \mathrm{C}$. Data illustrate low numbered mesocosms in the A-web are strongly related to each other and high numbered barrels in the B-web are also strongly related, while temperature (odd or even numbers) were of no importance 


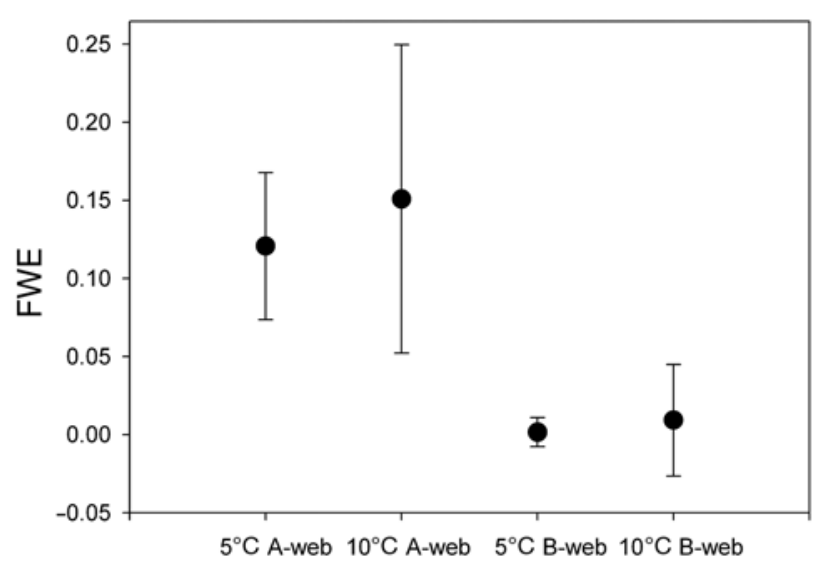

Fig. 8. Food web efficiency (FWE, without units) defined as amphipod biomass increment $\left(\mathrm{mg} \mathrm{C} \mathrm{dm}{ }^{-2} \mathrm{~d}^{-1}\right)$ normalized to phytoplankton production + bacterial production $\left(\mathrm{mg} \mathrm{C} \mathrm{dm}^{-2}\right.$ $\mathrm{d}^{-1}$ ). Values are mean $\pm \mathrm{SD}$ of 3 samplings

affected the amphipod growth in the experiments to a degree that had any effect on the major results. The differences in amphipod growth were not due to lower $\mathrm{C}$ production in the $\mathrm{B}$-webs since the sum of $\mathrm{C}$ production, the basal production, was higher in the B-webs. Instead, differences in food quality may explain the differences between the A-web and the B-web. The phytoplankton used in the experiment is known to contain storage lipids such as triacylglycerides and hydrocarbons, while bacteria do not store lipids at all (Larsson et al. 2000). In phytoplankton the proportion of $\mathrm{C}$ is higher than in bacteria; the molar $\mathrm{C}: \mathrm{N}: \mathrm{P}$ ratio of phytoplankton is $\sim 106: 16: 1$ (Redfield ratio), while that of bacteria is lower $~ 50: 10: 1$ (Stanier et al. 1978). Additionally, phytoplankton contains essential fatty acids, while most bacteria do not (Nichols \& McMeekin 2002). Thus, the stoichiometry and molecular composition of the food source may explain the variation in amphipod growth.

We considered whether food supply via sedimentation differed between the A-webs and the B-webs. Settling rates of plankton and aggregates greatly depend on the size of the particles (Smayda 1970) and consequently, bacteria have very low settling rates or simply do not settle, while large phytoplankton can have rates of $\sim 10 \mathrm{~m} \mathrm{~d}^{-1}$. It is therefore possible that there were differences in the benthic food supply in the A-webs and B-webs, even if the basal pelagic production was not very different in the 2 treatments. However, analysis of stable isotopes indicates that bacteria did settle out of the pelagic zone, since $\mathrm{C}$ found in the amphipods originated from the added glucose. The $\mathrm{N}$-signal in the amphipods did not indicate that the food web involved more trophic levels in B-webs, rather the opposite. This also indicates that bacteria were settling to the ben- thos. This may have been due to the short water column, $1 \mathrm{~m}$, in the incubation vessel, and that bacteria that feed on glucose may be relatively larger than naturally-occurring seawater bacteria. However, in all treatments the bacteria had an average cell length of $\sim 0.7 \mu \mathrm{m}$ and an abundance of $\sim 4 \times 10^{6}$ cells $\mathrm{ml}^{-1}$, indicating no major difference in bacterial sedimentation between the A- and the B-webs.

Thus, it was probably the short water column and the high production of the bacteria in the B-webs that led to significant settling of bacteria in those treatments. However, it is still likely that higher sedimentation did occur in the A-webs. The amphipod weights in the A and B-webs, respectively, at the first sampling were equal in spite of 5 times higher production in the Bwebs, which indicate that both the lower nutritional value in the bacterial web and the lower settling of $\mathrm{C}$ in those webs are of importance.

Since Monoporeia affinis is a deposit feeder with phytoplankton as the main $\mathrm{C}$ source and it prefers to feed from the sediment surface (Byrén et al. 2006), it might seem obvious that phytoplankton would be a better food source than bacteria. However, a previous study by Eriksson Wiklund et al. (2008) examined the effects of food quantity and quality on amphipod reproduction and reported that fecundity was positively correlated to sediment $\mathrm{C}$ content, but the effects on reproduction of different algal diets were small. However, since $\mathrm{C}$ from bacteria is considered to be of low nutritional value and is less likely to reach the sediment than $\mathrm{C}$ from a range of algal species, the differences in terms of food quality might be greater in our situation, thus explaining the large difference in amphipod weight.

Differences between treatments were small on the first sampling occasion, for which there are 2 possible explanations. First, we used a lower light intensity during the first weeks in order to acclimatise the benthic amphipods to the experimental conditions, but this clearly hampered the phytoplankton production. After acclimatisation the light intensity increased and the phytoplankton production escalated, leading to differences in amphipod growth between the food web treatments. Secondly, we added a thin layer of sediment, with a low $\mathrm{C}$ content, on top of the sand to prevent starvation during the first weeks and to produce a more natural environment for the amphipods. This small $\mathrm{C}$ addition might have been beneficial to the amphipods on the first sampling occasion, but its importance was substantially reduced after a few weeks.

We hypothesized that temperature would affect amphipod growth differently depending on food web. Higher temperature would reduce amphipod growth in the A-webs, due to decreased food supply caused by 
the reduction in phytoplankton sedimentation, previously shown in experiments by Müren et al. (2005). In the B-webs we expected the opposite result: increased growth in the $10^{\circ} \mathrm{C} \mathrm{B}$-web compared to the $5^{\circ} \mathrm{C} \mathrm{B}$-web because here nutrient supply was good, allowing the bacteria to respond to the higher temperature. We could only partly confirm our hypotheses. There was no significant difference between growth rates between the A-webs. However, the structure of the algal community in the A-webs changed from dominance by Chrysophyceae and Cyanophyceae to dominance by diatoms. This effect was most pronounced in the $5^{\circ} \mathrm{C}$ treatment. There was also a tendency towards a higher amphipod growth rate in the $5^{\circ} \mathrm{C} \mathrm{A}$-web compared to the $10^{\circ} \mathrm{C} \mathrm{A}$-web between the second and third sampling. Diatoms, which normally dominate the spring bloom, are regarded as high quality food resources compared to bacteria and other species of algae (Volkman et al. 1989, Ederington et al. 1995), although the experiment by Eriksson Wiklund et al. (2008) did not establish that diatoms are beneficial to Monoporeia affinis during the reproductive season. The results regarding the B-webs were in agreement with our hypothesis. A temperature increase from 5 to $10^{\circ} \mathrm{C}$ was expected to increase bacterial production in the B-web treatment. This was the case, as bacterial production was $35 \%$ higher in the $10^{\circ} \mathrm{C}$ incubation than in the $5^{\circ} \mathrm{C}$ treatment and both the weight and surface area of the amphipods were higher in the $10^{\circ} \mathrm{C}$ treatment. In fact, amphipod weight during the second part of the experiment was $\sim 30 \%$ higher in this treatment than in the $5^{\circ} \mathrm{C}$ incubation; this was similar to the observed increased bacterial production. This demonstrates that the amphipods in the $10^{\circ} \mathrm{C}$ B-web could compensate for the temperature-induced higher respiration compared to the amphipods in the $5^{\circ} \mathrm{C} B$-web by an increased food intake.

The studied amphipod is a stenothermal coldwater species and its sensitivity to increased temperature was recognized as early as 1904 by Samtner \& Weltner, who suggested (as did Larkin 1948) that $7^{\circ} \mathrm{C}$ is the upper limit for successful reproduction. Temperature has also been considered to be the most significant factor governing growth rate in the Baltic Sea (Segerstråle 1937). More recent research has shown that moderate temperature increases affect reproduction negatively (Eriksson Wiklund \& Sundelin 2001, Eriksson Wiklund \& Sundelin 2004, Jacobson et al. 2008). Monoporeia affinis has a $Q_{10}$ of 1.7 to 2.0 (Lehtonen \& Andersin 1998) and a rise in temperature of $3.2^{\circ} \mathrm{C}$ would increase the oxygen consumption of the amphipods by approximately 20 to $25 \%$ (Schmidt-Nielsen 1997), and likewise increase their metabolism. Our results indicate that there might be differences in temperature sensitivity between seasons and life stages and that juvenile amphipods can compensate a moderate temperature increase by increased feeding, i.e. if food is available. This may explain the occurrence of amphipods in shallow coastal areas in the northern Baltic Sea, showing high summer temperatures, since these habitats generally are more nutrient rich than off-shore areas.

The stable $\mathrm{N}$ isotope signal is supposed to reflect the number of trophic levels (Post 2002) and the enrichment is assumed to be 2 to $5 \%$ per trophic level. In mesozooplankton, the difference between an algaebased and a bacteria-based food web was $2.3 \%$ (Berglund et al. 2007). We found no differences between food webs or temperatures with respect to the stable $\mathrm{N}$ isotope signal for Monoporeia affinis, but we obtained values that were in the range of previously derived data for $M$. affinis (Nfon et al. 2008). The previously mentioned difference in the stable $\mathrm{C}$ isotope signal is due to the addition of glucose $\mathrm{C}$ which could be explained by a higher $\mathrm{C}^{13}$ ratio in the glucose $\mathrm{C}$ than in the $\mathrm{CO}_{2}$. Although the stable $\mathrm{N}$ isotope signal indicated no difference in food chain length, we found higher FWE in the A-webs. This may be explained by poorer food quality and sedimentation rates of bacteria than that of algae.

We expected that temperature would have an effect on the FWE in the A-webs, since large diatoms were disfavoured in the high temperature treatment and smaller algae settle at lower rates (Smayda 1970), therefore we expected the food supply to the amphipods to be lower in the $10^{\circ} \mathrm{C}$ incubation. By using the phytoplankton size distributions measured in our experiment and the sinking rate presented by Smayda (1970), we calculated that the sinking rate would have been $\sim 1.3$ and $0.6 \mathrm{~m} \mathrm{~d}^{-1}$ in the $5^{\circ} \mathrm{C}$ and $10^{\circ} \mathrm{C}$ treatments, respectively. Since the water column was only $\sim 1 \mathrm{~m}$ deep, it is likely that the entire primary production in the incubation vessels settled out within $\sim 1$ to $2 \mathrm{~d}$. The amphipods must, therefore, have been food saturated in both A-webs. Taken together, our data does not confirm the hypothesis that the higher temperature treatment results in a lower FWE in the Awebs. It is likely that this was due to a similar primary production in the 2 temperature treatments, a short water column leading to effective sedimentation of both small and large algae, food saturation, and that these amphipods have greater temperature tolerance outside the reproductive season.

It has been suggested that export of sinking organic $\mathrm{C}$ may be lower under future climatic scenarios (Laws et al. 2000, Bopp et al. 2001) and C export efficiency depends not only on $\mathrm{C}$ fixation but also on the community structure (Boyd \& Newton 1999). According to Tamelander et al. (2006), pelagic-benthic coupling has a high spatial variability and, in the Barents Sea, the 
linkage between surface primary production and benthic animal communities is mainly governed by rapidly settling diatom blooms. Estimates of settling from phytoplankton blooms in the Baltic Sea, published in several studies, show large differences. Höglander et al. (2004) reported that $12 \%$ of the production settled while others e.g. (Heiskanen \& Leppänen 1995) have reported a much higher export $(80 \%)$ to the benthos. Our results indicate that the indirect effects from an altered pelagic production have a larger impact on benthic productivity than an increased temperature under future climatic scenarios.

Comparing the results from this experiment with the dramatic population decline that occurred for the Monoporeia affinis populations in the Gulf of Bothnia a decade ago, we argue that it is possible that food shortage was one cause. Prior to the population decline these amphipods were living in very dense food-limited populations (Eriksson Wiklund et al. 2008) coinciding with a series of extreme weather events which would decrease the water transparency, and result in a higher ratio than normal between bacterial and phytoplankton production (SHARK data base, SMHI, Sweden). The most likely consequence of this was a reduction in $\mathrm{C}$ transport to the benthos. The combination of the dense food-limited populations and the decline in $\mathrm{C}$ export to the benthos could have been one of the key factors causing the decline. $M$. affinis is a semelparous organism with no possibility of postponing gonad development once it has begun (Sundelin et al. 2008). If the gonads remain unfertilized, they will degenerate and the females will die, resulting in a lost generation. In addition, it has been suggested that $M$. affinis needs to reach a threshold size (Leonardsson et al. 1988) or achieve a threshold lipid ratio of at least $20 \%$ to be able to reproduce (Hill et al. 1992).

Results from this study indicate that in a future climate perspective, the occurence of smaller phytoplankton species and increased importance of bacterial production, leading to decreased transport of $\mathrm{C}$ to benthos and reduced food quality, may have an additive negative effect on benthic productivity in areas such as the northern Baltic Sea.

Acknowledgements. This study was supported by grants from the Swedish Research Council for Environment, Agricultural Sciences and Spatial Planning to A.A. (No. 21.0/2004-0376) and the Carl Tryggers foundation to A.-K.E.W. We thank the personnel at the Umeå Marine Sciences Centres for technical assistance, Dr. Erik Lundberg for chemical analyses, and Peter Mathisen for plankton analyses.

\section{LITERATURE CITED}

Aljetlawi AA (2003) Effects of size and survival in a deposit feeding amphipod Monoporeia affinis in the Gulf of Bothnia (N. Baltic Sea). Thesis, Umeå University, Umeå
Aljetlawi AA, Albertsson J, Leonardsson K (2000) Effect of food and sediment pre-treatment in experiments with a deposit-feeding amphipod Monoporeia affinis. J Exp Mar Biol Ecol 249:263-280

- Andersson A, Selstam E, Hagström Å (1993) Vertical transport of lipid in seawater. Mar Ecol Prog Ser 98:149-155

Andersson A, Haecky P, Hagström Å (1994) Effect of temperature and light on the growth of micro-nano- and picoplankton: impact on algal succession. Mar Biol 120: 511-520

Andersson A, Hajdu S, Haecky P, Kuparinen J, Wikner J (1996) Succession and growth limitation of phytoplankton in the Gulf of Bothnia (Baltic Sea). Mar Biol 126:791-801

Berglund J, Muren U, Båmstedt U, Andersson A (2007) Efficiency of a phytoplankton-based and a bacteria-based food web in a pelagic marine system. Limnol Oceanogr 52: 121-131

Blackburn N, Hagström A, Wikner J (1998) Rapid determination of bacterial abundance, biovolume, morphology, and growth by neural network-based image analysis. Appl Environ Microbiol 64:3246-3255

Bopp L, Monfray P, Aumont O, Dufresne JL and others (2001) Potential impacts of climate change on marine export production. Global Biogeochem Cycles 15:81-99

Boyd PW, Newton PP (1999) Does planktonic community structure determine downward particulate organic carbon flux in different oceanic provinces? Deep-Sea Res I 46: 63-91

Byrén L, Ejdung G, Elmgren R (2006) Uptake of sedimentary organic matter by the deposit-feeding Baltic amphipods Monoporeia affinis and Pontoporeia femorata. Mar Ecol Prog Ser 313:135-143

Cederwall H (1977) Annual macrofauna production of a soft bottom in the northern Baltic proper. In: Keegan BF, O'Ceidigh P, Boaden PJS (eds) Biology of benthic organisms. Pergamon Press, Oxford, p 155-164

Ederington MC, McManus GB, Harvey HR (1995) Trophic transfer of fatty acids, sterols, and a triterpenoid alcohol between bacteria, a ciliate, and the copepod Acartia tonsa. Limnol Oceanogr 40:860-867

> Eriksson Wiklund AK, Sundelin B (2001) Impaired reproduction of the amphipods Monoporeia affinis and Pontoporeia femorata as a result of moderate hypoxia and increased temperature. Mar Ecol Prog Ser 222:131-141

Eriksson Wiklund AK, Sundelin B (2004) Biomarker sensitivity to temperature and hypoxia - a seven year field study. Mar Ecol Prog Ser 274:209-214

- Eriksson Wiklund AK, Sundelin B, Rosa R (2008) Population decline of amphipod Monoporeia affinis in Northern Europe: consequence of food shortage and competition? J Exp Mar Biol Ecol 367:81-90

> Fuhrman JA, Azam F (1982) Thymidine incorporation as a measure of heterotrophic bacterioplankton productivity in marine surface waters: evaluation and field results. Mar Biol 66:109-120

Gargas E (1975) A manual for phytoplankton productivity studies in the Baltic. Baltic Marine Biologists. Publication No. 2. Water Quality Institute, Horsholm

Grasshoff K, Ehrhardt M, Kremling K (1983) Methods of sea water analysis. Verlag Chemie, Weinheim

> Hare CE, Leblanc K, DiTullio GR, Kudela RM and others (2007) Consequences of increased temperature and $\mathrm{CO}_{2}$ for phytoplankton community structure in the Bering Sea. Mar Ecol Prog Ser 352:9-16

Heiskanen AS, Leppänen JM (1995) Estimation of export production in the coastal Baltic Sea: effect of resuspension and microbial decomposition on sedimentation measure- 
ments. Hydrobiologia 316:211-224

HELCOM (2007) Climate change in the Baltic Sea areaHELCOM thematic assessment in 2007. Baltic Sea Environment Proc No. 111

Hill C, Quigley MA, Cavaletto JF, Gordon W (1992) Seasonal changes in lipid content and composition in the benthic amphipods Monoporeia affinis and Pontoporeia femorata. Limnol Oceanogr 37:1280-1289

Höglander H, Larsson U, Hajdu S (2004) Vertical distribution and settling of spring phytoplankton in the offshore NW Baltic Sea proper. Mar Ecol Prog Ser 283:15-17

Jacobson T, Prevodnik A, Sundelin B (2008) Combined effects of temperature and a pesticide on the Baltic amphipod Monoporeia affinis. Aquat Biol 1:269-276

Karlson K, Bonsdorff E, Rosenberg R (2007) The impact of benthic macrofauna for nutrient fluxes from Baltic Sea sediments. Ambio 36:161-167

Keller AA, Oviatt CA, Walker HA, Hawk JD (1999) Predicted impacts of elevated temperature on the magnitude of the winter-spring phytoplankton bloom in temperate coastal waters: a mesocosm study. Limnol Oceanogr 44:344-356

Kotta J, Ólafsson E (2003) Competition for food between the introduced polychaete Marenzelleria viridis (Verril) and the native amphipod Monoporeia affinis (Lindström) in the Baltic Sea. J Sea Res 50:27-35

Laine AO, Sandler H, Andersin AB, Stigzelius J (1997) Longterm changes of macrozoobenthos in the Eastern Gotland Basin and the Gulf of Finland (Baltic Sea) in relation to the hydrographical regime. J Sea Res 38:135-159

Larkin PA (1948) Pontoporeia and Mysis in Athabaska, Great Bear and Great Slave Lakes. Bull Fish Res Board Can 88

Larsson P, Andersson A, Broman D, Nordbäck J, Lundberg E (2000) Persistent organic pollutants (POPs) in pelagic systems. Ambio 29:202-209

> Laws EA, Falkowski PG, Smith WO, Ducklow H, McCarthy JJ (2000) Temperature effects on export production in the open ocean. Global Biogeochem Cycles 14:1231-1246

Lehtonen KK (1994) Metabolic effects of short-term starvation on the benthic amphipod Pontoporeia affinis (Lindström) from the northern Baltic Sea. J Exp Mar Biol Ecol 176: 269-283

Lehtonen KK, Andersin AB (1998) Population dynamics, response to sedimentation and role in benthic metabolism of the amphipod Monoporeia affinis in an open-sea area of the northern Baltic Sea. Mar Ecol Prog Ser 168:71-85

> Leonardsson K, Sörlin T, Samberg H (1988) Does Pontoporeia affinis optimize age at reproduction in the Gulf of Bothnia. Oikos 52:328-336

Meier HEM (2006) Baltic Sea climate change in the late twenty-first century: a dynamical downscaling approach using two global models and two emission scenarios. Clim Dyn 27:39-68

Menden-Deuer B, Lessard EJ (2000) Carbon to volume ratio relationships for dinoflagellates, diatoms and other protist plankton. Limnol Oceanogr 45:569-579

Müren U, Berglund J, Samuelsson K, Andersson A (2005) Potential effects of elevated sea-water temperature on pelagic food webs. Hydrobiologia 545:153-166

Nalepa TF, Fanslow DL, Foley AJ III, Lang GA, Eadie BJ, Quigley MA (2006) Continued disappearance of the benthic amphipod Diporeia spp. in Lake Michigan: Is there evidence for food limitation? Can J Fish Aquat Sci 63: 872-890

> Nfon E, Cousins IT, Broman D (2008) Biomagnification of organic pollutants in benthic and pelagic marine food chains from the Baltic Sea. Sci Total Environ 397:190-204

Editorial responsibility: Inna Sokolova,

Charlotte, North Carolina, USA
Nichols DS, McMeekin TA (2002) Biomarker techniques to screen for bacteria that produce polyunsaturated fatty acids. J Microbiol Methods 48:161-170

Norland S (1993) The relationship between biomass and volume of bacteria. In: Kemp PH, Sherr BF, Sherr EB, Cole JJ (eds) Handbook of methods in aquatic microbial ecology. Lewis Publishers, London p 303-307

Olenina I, Hajdu S, Edler L, Andersson A and others (2006) Biovolumes and size-classes of phytoplankton in the Baltic Sea. Baltic Sea Environment Proc No. 106

Post DM (2002) Using stable isotopes to estimate trophic position: models, methods, and assumptions. Ecology 83: 703-718

Samtner M, Weltner W (1904) Biologische Eigentümlichkeiten der Mysis relicta, Pallasiella quadrospinosa und Pontoporeia affinis erklärt aus ihrer eiszeitlichen Entstehung. Zool Anz 27:676-694

Samuelsson K, Berglund J, Haecky P, Andersson A (2002) Structural changes in an aquatic microbial food web caused by inorganic nutrient addition. Aquat Microb Ecol 29:29-38

Samuelsson K, Berglund J, Andersson A (2006) Factors structuring the heterotrophic nanoflagellate and ciliate community along a brackish water productivity gradient. J Plankton Res 28:345-359

Sandberg J, Andersson A, Johansson S, Wikner J (2004) Pelagic food web structure and carbon budget in the northern Baltic Sea: potential importance of terrigenous carbon. Mar Ecol Prog Ser 268:13-29

Schmidt-Nielsen K (1997) Animal physiology: adaptation and environment, 5th edn. Cambridge University Press, Cambridge

Segerstråle SG (1937) Studien über die Bodentiervelt in sudfinländischen Küsterngewässern III. Zur Morphologie und Biologie des Amphipoden Pontoporeia affinis nebst einer Revision der Pontoporeia-Systematik. Commentat Biol Soc Sci Fenn 7:1-183

Smayda T (1970) The suspension and sinking of phytoplankton in the sea. Oceanogr Mar Biol Annu Rev 8:353-414

Sommer U, Aberle N, Engel A, Hansen T and others (2007) An indoor mesocosm system to study the effect of climate change on the late winter and spring succession of Baltic Sea phyto- and zooplankton. Oecologia 150:655-667

Stanier RY, Adelberg EA, Ingraham JL (1978) General microbiology, 4th edn. Macmillan Press, London

Straile D (1997) Gross growth efficiencies of protozoan and metazoan zooplankton and their dependence on food concentration, predator-prey weight ratio, and taxonomic group. Limnol Oceanogr 42:1375-1385

Sundelin B, Eriksson Wiklund AK, Ford AT (2008) Biological effects of contaminants: the use of embryo aberrations in crustacean for measuring effects of environmental stressors. ICES Techniques Mar Environ Sci 41

Tamelander T, Renaud PE, Hop H, Carroll ML, Ambrose WG, Hobson KA (2006) Trophic relationships and pelagicbenthic coupling during summer in the Barents Sea Marginal Ice Zone, revealed by stable carbon and nitrogen isotope measurements. Mar Ecol Prog Ser 310:33-46

Volkman JK, Jefferey SW, Nichols PD, Rogers GI, Garland CD (1989) Fatty acid and lipid composition of ten species of microalgae used in mariculture. J Exp Mar Biol Ecol 128:219-240

Watkins JM, Dermott R, Lozano SJ, Mills EL, Rudstam LG, Scharold JV (2007) Evidence for remote effects of dreissenid mussels on the amphipod Diporeia: analysis of Lake Ontario benthic surveys, 1972-2003. J Gt Lakes Res 33: 642-657

Submitted: March 20, 2009; Accepted: September 1, 2009

Proofs received from author(s): November 16, 2009 